\title{
Abiotic formation of organic biomorphs under diagenetic conditions
}

\author{
I. Criouet ${ }^{1}$, J.-C. Viennet ${ }^{1}$, P. Jacquemot ${ }^{1,2}$, M. Jaber ${ }^{2}$, S. Bernard ${ }^{1 *}$
}

Abstract

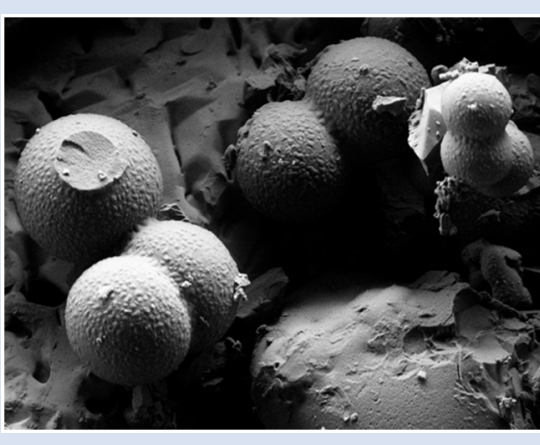

The most ancient fossil record contains fundamentally important information on both the diversity and disparity of ancient life. Yet this ancient record is not that easy to decode, due to difficulties mainly pertaining to the impact of the geological history. Thus, the convergence of multiple lines of evidence is seen as necessary to build a robust demonstration of the biogenicity of putative traces of life. Yet, we experimentally show here that abiotic organic cell-like microstructures meeting all the criteria of biogenicity may form in cherts under classical conditions of diagenesis. These organic biomorphs produced from a mixture of RNA and quartz in water exposed to temperature and pressure conditions $\left(200^{\circ} \mathrm{C}, \sim 15\right.$ bars) exhibit morphological, chemical and isotopic signatures typical of organic microfossils. The results of this study exemplify the pitfalls that Archean palaeontologists may encounter when searching for traces of life in ancient rocks.

Received 15 July 2020 | Accepted 1 December 2020 | Published 20 January 2021

\section{Letter}

We still do not know when, where and how life started to exist on Earth. As the unique source of direct information about past life, the ancient fossil record may provide answers. Yet, although the ancient fossil record may contain fundamentally important 'biogeochemical' signals, its quality is far from perfect, making it not that easy to decode (Brasier et al., 2006; Javaux, 2019). Archean palaeontology only relies on degraded signals difficult to interpret, as illustrated by the number of controversies having so far hindered the search for the most ancient traces of life on Earth (Schopf, 1975; Javaux, 2019).

A main difficulty is the lack of a univocal criterion to rely on when discussing the biogenicity of putative remains of life in ancient rocks: neither the carbon isotopic compositions nor the morphologies should be seen as unambiguous biosignatures (Craig, 1954; Horita, 2005; Cosmidis and Templeton, 2016; Garcia-Ruiz et al., 2020). In fact, mineral biomorphs may easily be produced experimentally via self-assembly processes (GarciaRuiz et al., 2003) and may exhibit high levels of complexity (Garcia-Ruiz et al., 2009; Noorduin et al., 2013; Rouillard et al., 2018). Worse still, Cosmidis and Templeton (2016) recently demonstrated that carbon-sulfur biomorphs could also be produced.

Chemical information may help to identify remains of life (Benzerara et al., 2006; Bernard et al., 2007; Alleon et al., 2018; Loron et al., 2019), but abiotic processes may lead to the formation of disordered carbonaceous materials difficult to distinguish from biogenic ones (Pasteris and Wopenka, 2003; De Gregorio et al., 2011). Collectively, because none of the criteria commonly used to discuss biogenicity are sufficient in themselves, many authors have emphasised the need for gathering multiple lines of evidence to demonstrate convincingly the biological origin of any putative remain of life in ancient cherts (e.g., Westall, 2005; Wacey, 2009; Bernard and Papineau, 2014; Javaux, 2019). Yet, as illustrated by the present study, purely abiotic microstructures may fulfill not only a couple but many (if not all) of the commonly used criteria of biogenicity, i.e. morphological, chemical and isotopic criteria, even the most conservative ones ( $c f$. below).

Here, we exposed RNA (i.e. the most emblematic organic molecule of the prebiotic RNA World; Higgs and Lehman, 2015) to thermal conditions typical of diagenesis $\left(200^{\circ} \mathrm{C}\right)$, in pure bidistilled water under an autogenic pressure of 15 bars, in the presence of quartz (i.e. the main mineral of Archean cherts; Perry and Lefticariu, 2007) and under an argon atmosphere for 20 days. We conducted additional experiments under the same conditions with RNA in the absence of quartz and with quartz in the absence of RNA to serve as controls. The water insoluble experimental residues were characterised using $X$-ray diffraction (XRD), isotopic ratio mass spectrometry (IRMS), solid-state ${ }^{13} \mathrm{C}$ cross polarization magic-angle spinning nuclear magnetic resonance $\left({ }^{13} \mathrm{C}\right.$ CP MAS NMR) and Fourier transform infrared (FTIR) spectroscopies. Additional characterisation was conducted using advanced microscopy and spectroscopy tools including scanning electron microscopy (SEM) coupled with energy dispersive X-ray spectroscopy (EDXS), scanning transmission electron microscopy (STEM) and scanning transmission X-ray microscopy (STXM) coupled with X-ray absorption near edge structure (XANES) spectroscopy.

\footnotetext{
1. Muséum National d'Histoire Naturelle, Sorbonne Université, CNRS UMR 7590, Institut de Minéralogie, Physique des Matériaux et Cosmochimie, Paris, France

2. Laboratoire d'Archéologie Moléculaire et Structurale, CNRS UMR 8220, Institut des Matériaux de Paris, Sorbonne Université, F-75005, Paris, France

Corresponding author (email: sbernard@mnhn.fr)
} 


\section{(a) XRD}

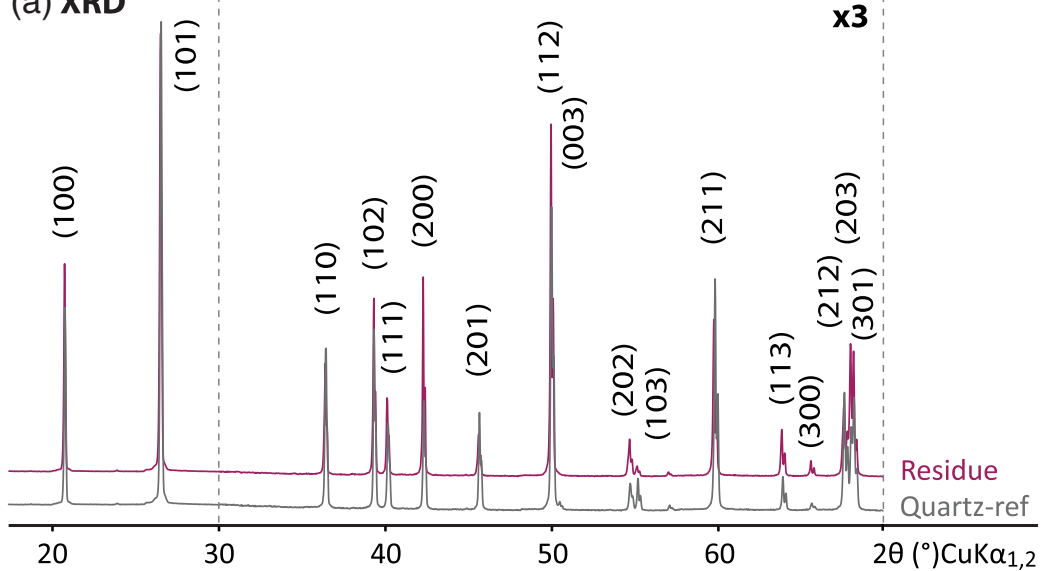

(b) FTIR

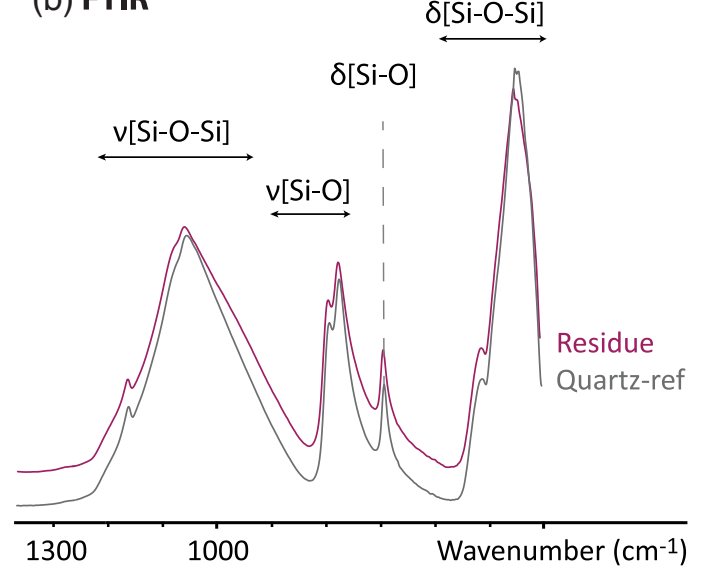

Figure 1 XRD and FTIR results. (a) Powder XRD patterns of the experimental residue ( $\alpha$-quartz $+\mathrm{RNA}+\mathrm{H}_{2} \mathrm{O}$ at $200^{\circ} \mathrm{C}, 15$ bars, 20 days) and of the $\alpha$-quartz reference (intensity increased $\times 3$ from 30 to $70^{\circ} 2 \theta$ ). (b) ATR-FTIR spectra of the experimental residue ( $\alpha$-quartz + RNA $+\mathrm{H}_{2} \mathrm{O}$ at $200^{\circ} \mathrm{C}, 15$ bars, 20 days) and of the $\alpha$-quartz reference.

Quartz was relatively unaffected by the experimental conditions. The main peaks of the XRD pattern of the experimental residue are those of $\alpha$-quartz (i.e. $4.47 \AA(100), 3.40 \AA$ (101) and $2.57 \AA$ (110); Fig. 1a). Likewise, the FTIR spectrum of the residue exhibits absorption bands typical of $\alpha$-quartz (Fig. 1b): Si-O-Si and Si-O bending vibrations at $455 \mathrm{~cm}^{-1}, 514 \mathrm{~cm}^{-1}$ and $694 \mathrm{~cm}^{-1}$, Si-O stretching vibrations at 775 and $794 \mathrm{~cm}^{-1}$ and Si-O-Si stretching vibrations at 1052 and $1160 \mathrm{~cm}^{-1}$ (Fig. 1b; Anbalagan et al., 2010). Nevertheless, SEM images reveal the presence of dissolution pits at the surface of quartz grains, indicating that a certain fraction of quartz dissolved during the experiment (Fig. 2a).

Most importantly, SEM images show the presence, at the surface of the quartz grains, of newly formed spheroidal carbonaceous microstructures (Fig. 2), resembling micro-organisms such as Staphylococcus or Thermococcales (Fig. 2i,j). Arranged in clusters, these spheroidal organic biomorphs exhibit a rather restricted range of diameters of about $\sim 0.5$ to $\sim 5 \mu \mathrm{m}(\mu=2.03$ $\mu \mathrm{m}$; Fig. 2c). Most display a rough surface resembling the ultrastructure of living cells, and many are connected together as if they were microbes encompassing cell division (Fig. 2). These spheroidal organic biomorphs exhibit N/C values of 0.1 (vs. 0.4 for RNA), $\delta^{13} \mathrm{C}$ values of $-19.35 \pm 0.04 \%$ (vs. $-22.62 \pm$ $0.04 \%$ o for RNA) and $\delta^{15} \mathrm{~N}$ values of $-9.95 \pm 0.09 \%$ (vs. $-12.11 \%$ o $\pm 0.09 \%$ o for RNA), i.e. values not that different from those expected for organic microfossils (e.g., Craig, 1954; Mojzsis et al., 1996; Horita, 2005).

While the NMR spectrum of RNA is dominated by the signals of ribose (between 60 and 105 ppm) and nucleobases (between 140 and $170 \mathrm{ppm}$ ), the NMR spectrum of these spheroidal organic biomorphs indicates the presence of aliphatic, aromatic and heterocyclic carbons (signals from 0 to $50 \mathrm{ppm}, 100$ to 130, and 130 to 150 ppm respectively) and amide and ketone groups (features at 170 and $200 \mathrm{ppm}$ ) (Fig. 3a; Jacquemot et al., 2019). This is in line with the FTIR spectrum showing C-H bending vibrations at $1367 \mathrm{~cm}^{-1}$, aromatic $\mathrm{C}=\mathrm{C}$ stretching vibrations at $1442 \mathrm{~cm}^{-1}$ and $\mathrm{CH}_{3} / \mathrm{CH}_{2}$ stretching vibrations from 2850 to $2980 \mathrm{~cm}^{-1}$ (Fig. 3b). The additional features at $1594 \mathrm{~cm}^{-1}$ and $1675 \mathrm{~cm}^{-1}$ highlight the presence of $\mathrm{N}-\mathrm{H}$ bonds in amides or amines, as well as $\mathrm{C}=\mathrm{N}$ bounds in imines or $\mathrm{C}=\mathrm{O}$ bounds in ketones (Fig. 3b; Li et al., 2014; Bernard et al., 2015).

In contrast to RNA which C-XANES spectrum exhibits a number of well defined absorption features attributed to nucleobases and ribose (Fig. 4; Viennet et al., 2019, 2020), the spheroidal organic biomorphs display a XANES spectrum with large features attributed to (hetero)quinones and olefinic or aromatic carbons (284.8-285.5 eV), imines, nitriles, ketones and/or phenols (286.4 eV) and amide groups (288.2 eV) (Fig. 4; Le Guillou et al., 2018), i.e. a spectrum not that different from those expected for microfossils. The N-XANES spectrum confirms the presence of imine/nitrile (peaks at 398.3 and $399.4 \mathrm{eV}$ ) and amide functions (feature at $401.5 \mathrm{eV}$ ) (Fig. 4; Alleon et al., 2017). Control experiments revealed that the presence of quartz has no influence on the properties of the produced spheroidal organic biomorphs (Fig. S-1).

By analogy with the production of hydrothermal carbon spheres (a.k.a. hydrochars), it can be assumed that the formation of these spheroidal organic biomorphs resulted from a cascade of reactions involving hydrolysis, dehydration, aromatisation and condensation (LaMer, 1952; Sevilla and Fuertes, 2009a,b). The entire process should not be seen as a suite of consecutive reactions, but rather as a parallel network of different reaction paths (Funke and Ziegler, 2010; Hu et al., 2010). The hydrolysis of RNA likely produced organic acids having accelerated dehydration and fragmentation processes (i.e. ring opening and bond breaking), forming soluble by-products such as furfural-like compounds (Sevilla and Fuertes, 2009a,b). These by-products likely underwent aromatisation and condensation (possibly via intermolecular dehydration), leading to the production of aromatic clusters (Sevilla and Fuertes, 2009a,b). Burst nucleation processes likely took place when the concentration of aromatic clusters reached the critical supersaturation point, the nuclei growing by diffusion to the surface of the chemical species present in the solution, eventually forming the spheroidal organic biomorphs (Sevilla and Fuertes, 2009a,b). According to the LaMer model (LaMer, 1952), the structure of these spheroidal organic biomorphs should be composed of an aromaticrich hydrophobic core and a hydrophilic surface containing a larger concentration of reactive oxygen-rich functional groups, as observed for hydrochars (Baccile et al., 2009; Sevilla and Fuertes, 2009a,b; Higgins et al., 2020). Yet, spatially resolved STXM investigations reveal that the spheroidal organic biomorphs produced here are quite homogeneous chemically, at least at the submicrometre scale, with rather equivalent concentrations of aromatic, ketone and amide groups inside their core and at their surface. 

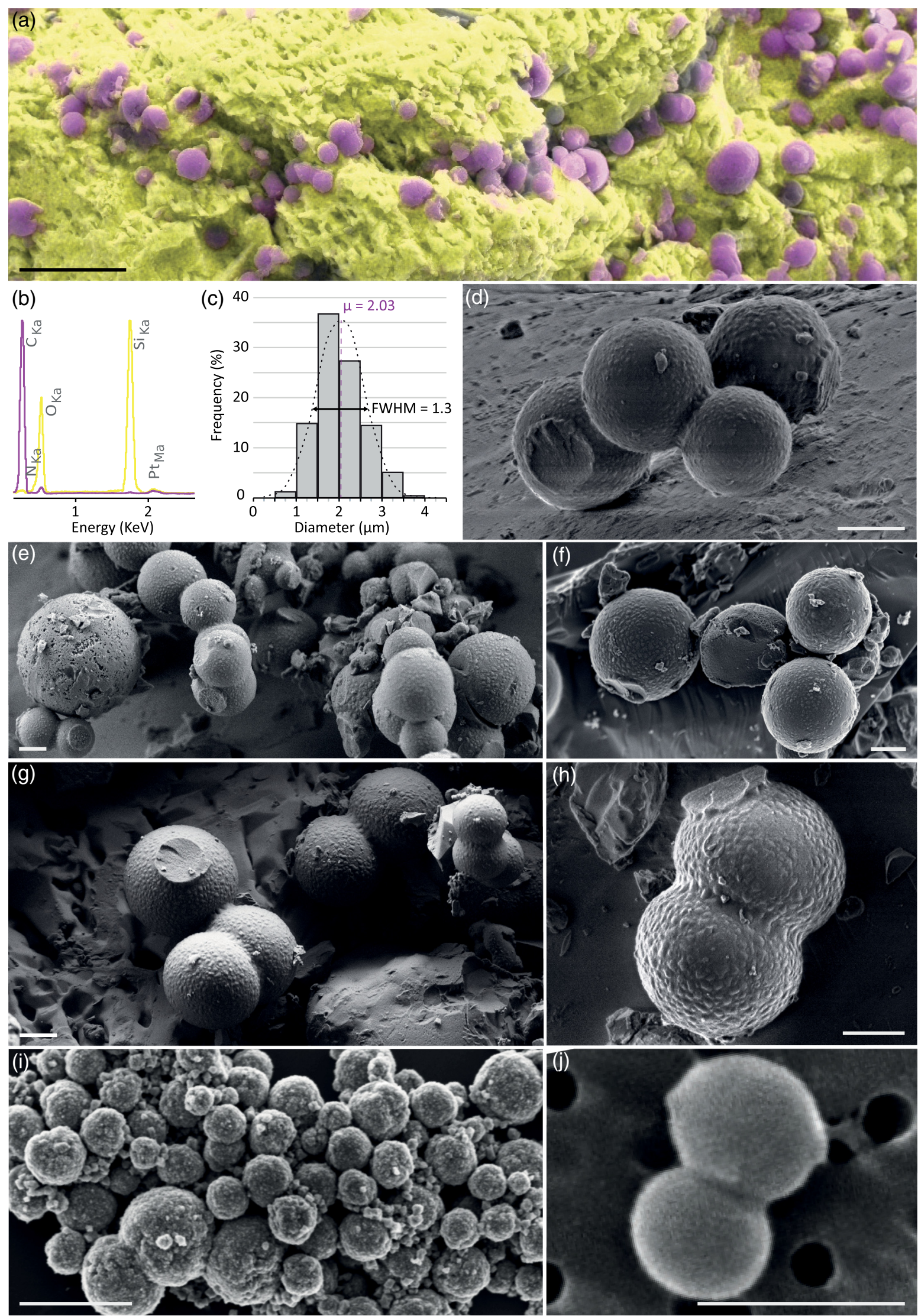

Figure 2 SEM investigations of the experimental residue ( $\alpha$-quartz $+\mathrm{RNA}+\mathrm{H}_{2} \mathrm{O}$ at $200^{\circ} \mathrm{C}, 15$ bars, 20 days). (a) EDX map of the residue and (b) corresponding EDX spectra. Quartz appears in yellow and the spheroidal organic biomorphs appear in purple. (c) Bar chart showing the size distribution of the spheroidal organic biomorphs produced during the experiments (FWHM: full width at half maximum). (e-h) SEM images (secondary electrons) of the spheroidal organic biomorphs produced during the experiments. (f, g) SEM images (secondary electrons) of Thermococcus prieurii cells (courtesy of Aurore Gorlas). Scale bars: (a) $10 \mu \mathrm{m},(\mathbf{d}-\mathrm{j}) 1 \mu \mathrm{m}$. 
(a) NMR

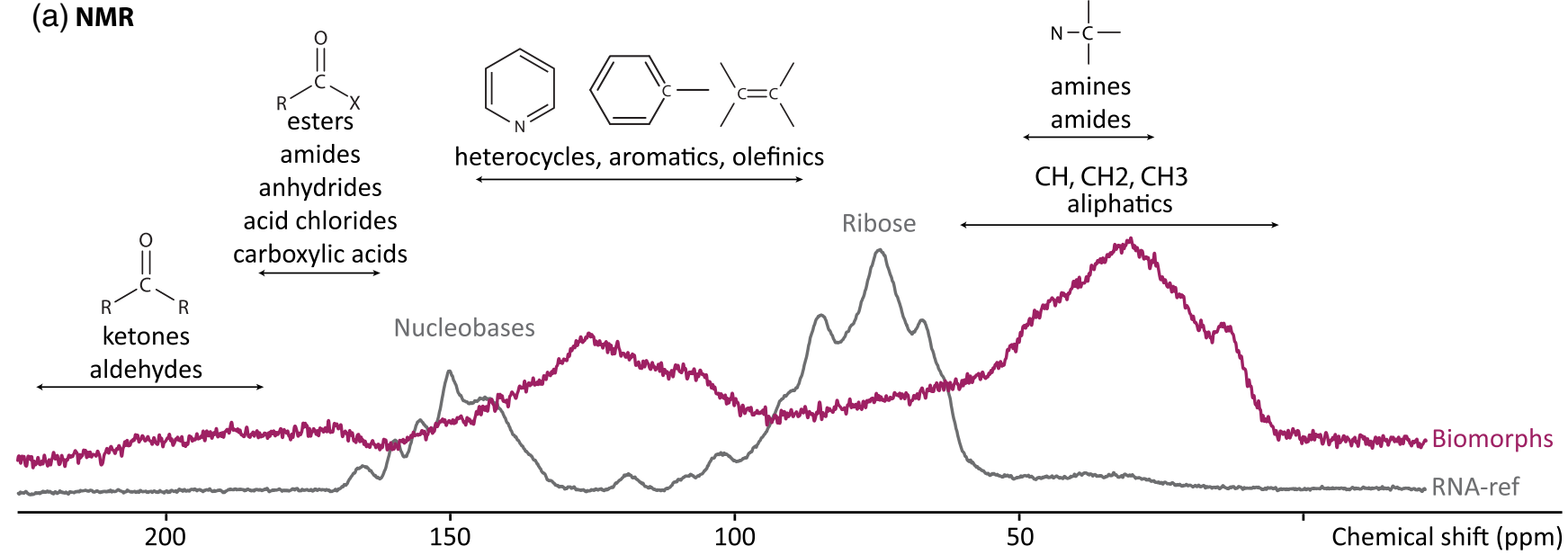

\section{(b) FTIR}

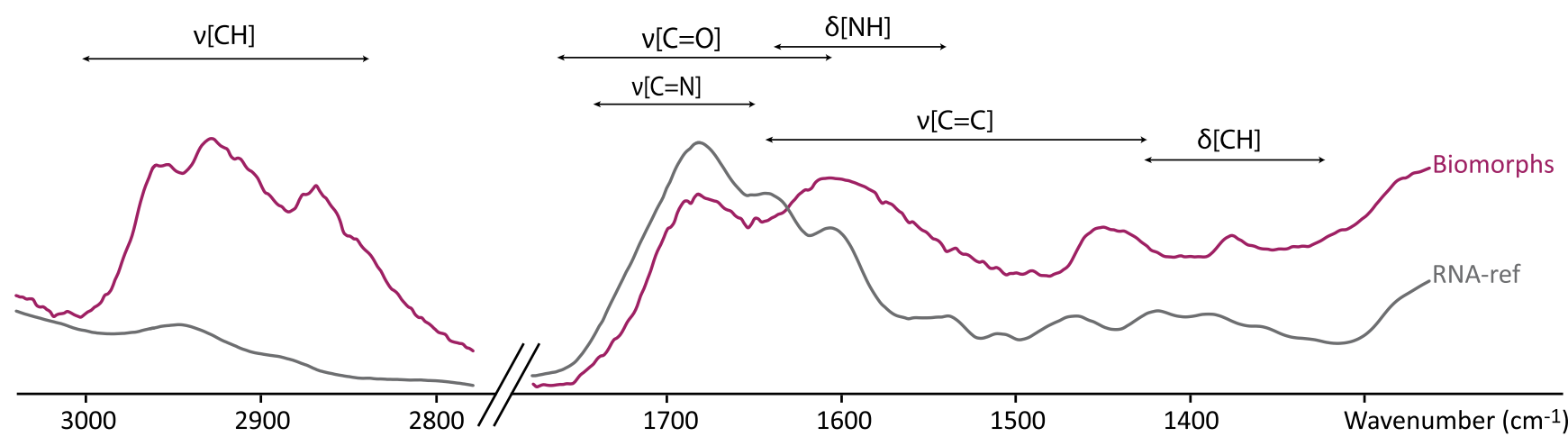

Figure 3 Solid state ${ }^{13} \mathrm{C}$ NMR and ATR-FTIR results. (a) Solid state ${ }^{13} \mathrm{C} C P$ MAS NMR spectra of the experimental residue $(\alpha-q u a r t z+R N A+$ $\mathrm{H}_{2} \mathrm{O}$ at $200^{\circ} \mathrm{C}, 15$ bars, 20 days) and of the RNA reference. Spectra are normalised to the quantity of carbon. (b) ATR-FTIR spectra of the experimental residue ( $\alpha$-quartz $+\mathrm{RNA}+\mathrm{H}_{2} \mathrm{O}$ at $200^{\circ} \mathrm{C}, 15$ bars, 20 days) and of the RNA reference. Spectra are normalised to the total carbon content. Note that the intensity of the signals were increased $\times 3$ for clarity from $\sim 3035$ to $\sim 2775 \mathrm{~cm}^{-1}$.

Collectively, in contrast to mobile hydrocarbon microspheres that can be encountered in the geological record (Wanger et al., 2012), the spheroidal organic biomorphs produced here exhibit all the morphological and geochemical features typical of organic microfossils (size, morphology, ultrastructure, chemistry, isotopic signatures). Worse still, it has been shown that, if exposed to pressure and temperature conditions typical of the geological history undergone by ancient cherts, such spheroidal organic biomorphs may evolve into double shell hollow spheres (Hu et al., 2010; Li et al., 2016). In other words, because they meet all the criteria commonly used to discuss biogenicity, even the most conservative ones (Brasier et al., 2006), the abiotic spheroidal organic biomorphs described here would logically be recognised as truly biogenic organic microfossils if they were found in ancient cherts.

The results of the present study exemplify the pitfalls that Archean palaeontologists may encounter when searching for traces of life in ancient rocks (e.g., Schopf, 1975; Javaux, 2019). It is clear that if new strategies are not adopted, ambiguities and controversies will persist. Advanced spatially resolved spectroscopy techniques may provide some clues regarding the molecular structure of putative organic microfossils (e.g. Brasier et al., 2015; Alleon and Summons, 2019), but this is not sufficient. Because unambiguously determining the exact nature of putative organic microfossils requires information on their original chemical nature, only laboratory experiments may provide the necessary constraints to eventually decode the most ancient fossil record (e.g., Javaux, 2019).

\section{Author Contributions}

IC, PJ and SB designed the present study. IC and PJ performed the NMR analyses. IC, PJ and SB performed the SEM analyses. IC and JCV performed the EA-IRMS analyses, the XRD analyses and the FTIR analyses. IC, JCV and SB performed the STXM analyses. All authors contributed to the interpretation of the data and discussed their implications. IC, JVC and SB wrote the manuscript, with critical inputs from PJ and MJ.

\section{Acknowledgements}

We acknowledge the support of the MNHN and of the IMPMC spectroscopy platform. We thank Elisabeth Malassis (IMPMC) for administrative support, Aurore Gorlas (I2BC) for SEM images of Thermococcus prieurii cells, Imène Esteve (IMPMC) for her help with SEM, Etienne Balan (IMPMC) for his help with FTIR, Denis Fiorillo (AASPE) for his help with EA-IRMS, Baptiste Rigaud (IMPC) for his help with NMR, David Troadec (IEMN) for the preparation of FIB sections, Corentin Le Guillou (UMET) for the TEM image and Sufal Swaraj (Soleil) for the expert support of the HERMES STXM beamline 


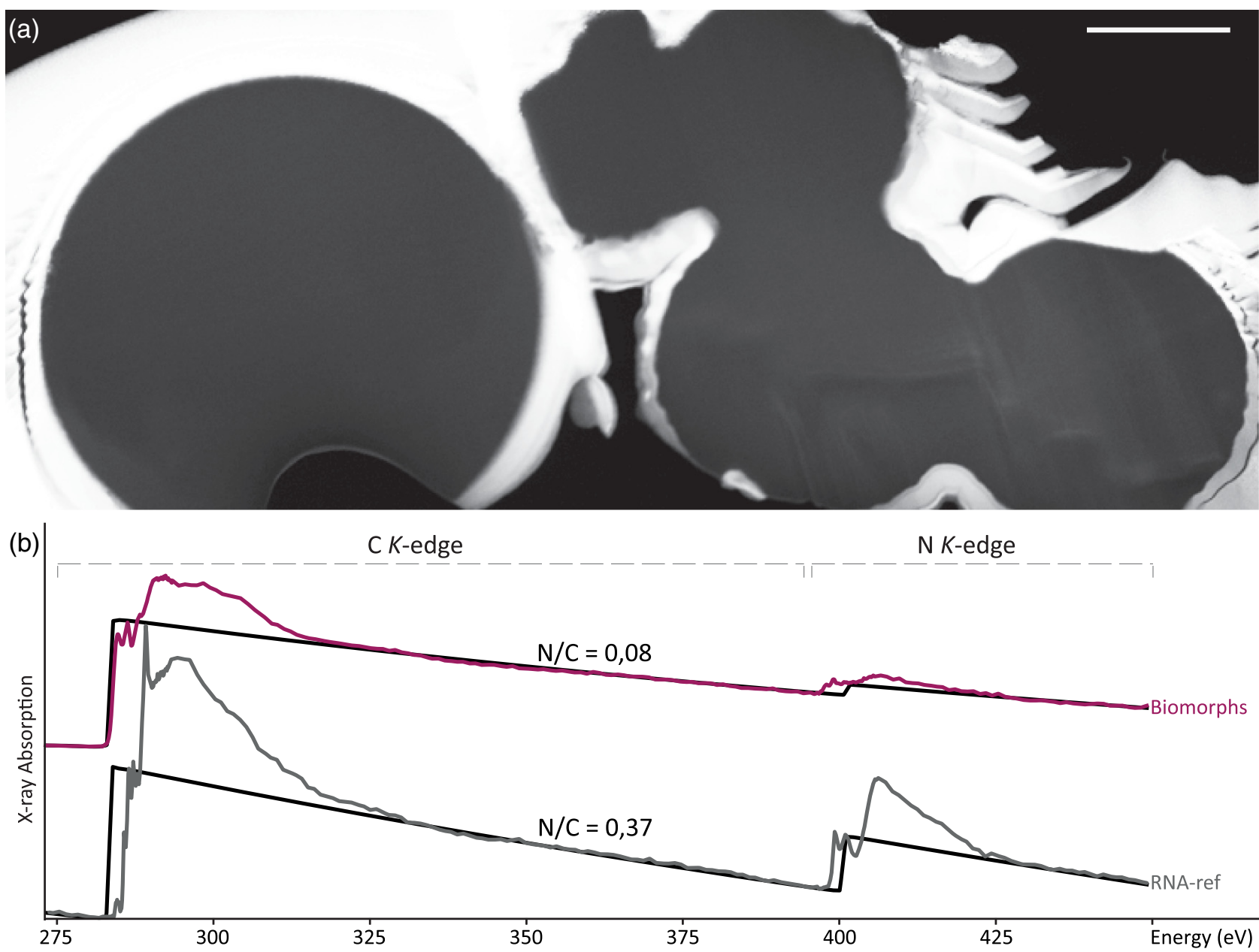

(c)
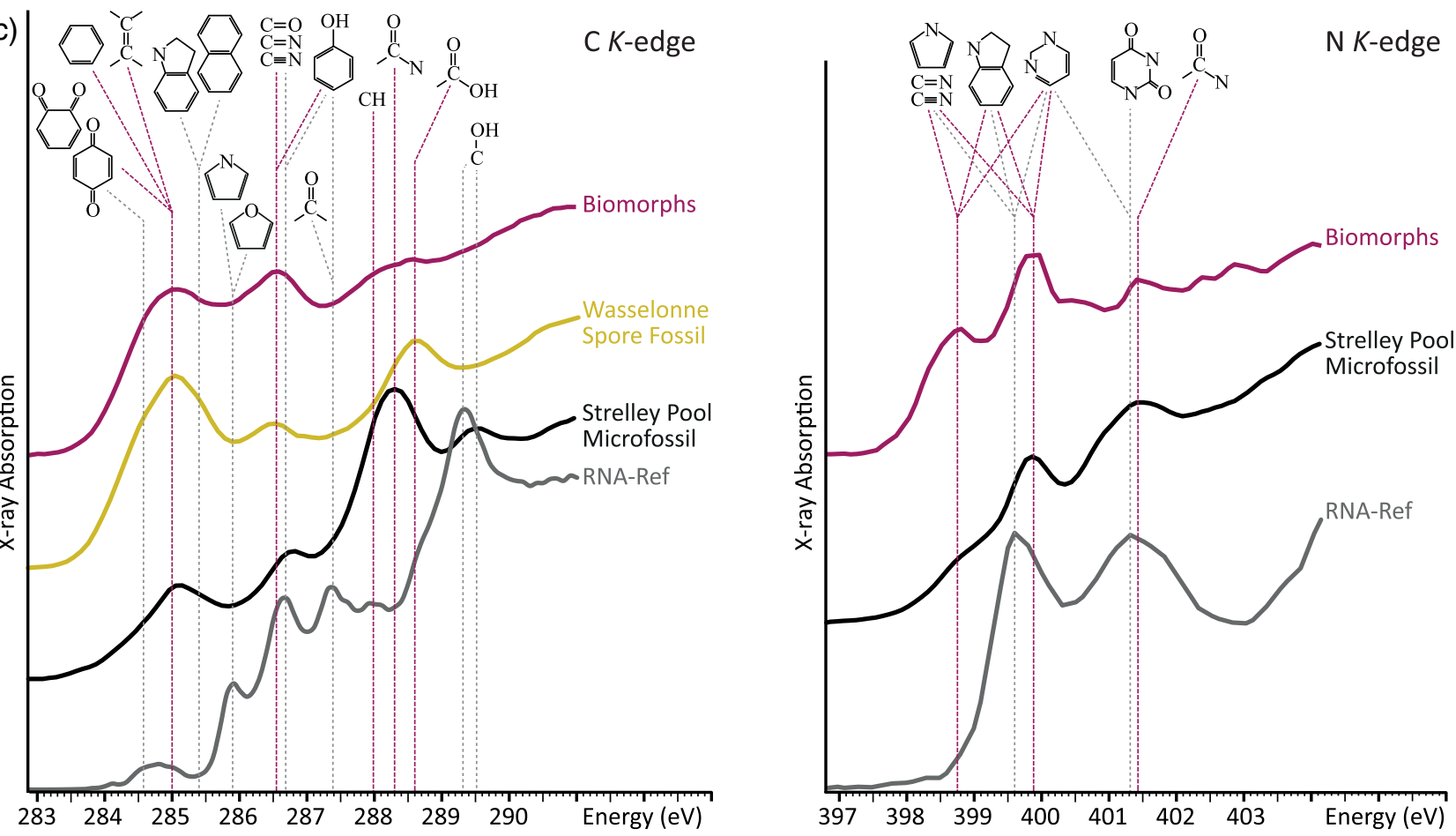

Figure 4 STEM and STXM-XANES results. (a) Transmission electron microscopy image (STEM mode) of the FIB section extracted from spheroidal organic biomorphs. Scale bar: $1 \mu \mathrm{m}$. (b) X-Ray absorption spectra of the organic biomorphs and of the RNA reference, with their corresponding N/C values. (c) C- and N-XANES spectra of the organic biomorphs and of the RNA reference compared to spectra of organic microfossils from Wasselonne (Bernard et al., 2009) and Strelley Pool (Alleon et al., 2018). All spectra are normalised to C and $\mathrm{N}$ quantities. 
at SOLEIL. The SEM facility at IMPMC is supported by Region Ile de France grant SESAME Number I-07-593/R, INSU-CNRS, INP-CNRS and UPMC-Paris 6, and by the Agence Nationale de la Recherche (ANR) grant number ANR-07-BLAN-0124-01. The TEM facility at the CCM (Lille University) is supported by the Chevreul Institute, the European FEDER, and Région Nord-Pas-de-Calais. The HERMES beamline (SOLEIL) is supported by the CNRS, the CEA, the Region Ile de France, the Departmental Council of Essonne and the Region Centre.

Editor: Satish Myneni

\section{Additional Information}

Supplementary Information accompanies this letter at https:// www.geochemicalperspectivesletters.org/article2102.

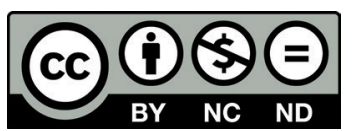

(C) 2021 The Authors. This work is distributed under the Creative Commons Attribution NonCommercial No-Derivatives 4.0 License, which permits unrestricted distribution provided the original author and source are credited. The material may not be adapted (remixed, transformed or built upon) or used for commercial purposes without written permission from the author. Additional information is available at https://www. geochemicalperspectivesletters.org/copyright-and-permissions.

Cite this letter as: Criouet, I., Viennet, J.-C., Jacquemot, P., Jaber, M., Bernard, S. (2021) Abiotic formation of organic biomorphs under diagenetic conditions. Geochem. Persp. Let. $16,40-46$.

\section{References}

Anbalagan, G., Prabakaran, A., Gunasekaran, S. (2010) Spectroscopic characterization of Indian standard sand. Journal of Applied Spectroscopy 77, 86-94.

Alleon, J., Bernard, S., Le Guillou, C., Daval, D., Skouri-Panet, F., Kuga, M., ROBERT, F. (2017) Organic molecular heterogeneities can withstand diagenesis. Scientific Reports 7, 1508.

Alleon, J., Bernard, S., Le Guillou, C., Beyssac, O., Sugitani, K., Robert, F. (2018) Chemical nature of the 3.4 Ga Strelley Pool microfossils. Geochemical Perspectives Letters 7, 37-42.

Alleon, J., Summons, R.E. (2019) Organic geochemical approaches to understand ing early life. Free Radical Biology and Medicine 140, 103-112.

Baccile, N., Laurent, G., Babonneau, F., Fayon, F., Titirici, M.-M., Antonietti, M (2009) Structural Characterization of Hydrothermal Carbon Spheres by Advanced Solid-State MAS ${ }^{13}$ C NMR Investigations. The Journal of Physical Chemistry C 113, 9644-9654

Benzerara, K., Menguy, N., Lopez-Garcia, P., Yoon, T.-H., KazmierczaK, J TyLiszcZAK, T., GuYot, F., Brown, G.E. (2006) Nanoscale detection of organic signatures in carbonate microbialites. Proceedings of the National Academy of Sciences 103, 9440-9445.

Bernard, S., Papineau, D. (2014) Graphitic Carbons and Biosignatures. Elements 10, $435-440$.

Bernard, S., Benzerara, K., Beyssac, O., Menguy, N., Guyot, F., Brownjr, G. Gorfe, B. (2007) Exceptional preservation of fossil plant spores in high pressure metamorphic rocks. Earth and Planetary Science Letters 262, $257-272$.

Bernard, S., Benzerara, K., Beyssac, O., Brown, G.E., Stamm, L.G., Duringer, P. (2009) Ultrastructural and chemical study of modern and fossil sporoderm by Scanning Transmission X-ray Microscopy (STXM). Review of Palaeobotany and Palynology 156, 248-261.

Bernard, S., Benzerara, K., Beyssac, O., Balan, E., Brown JR., G.E. (2015) Evolution of the macromolecular structure of sporopollenin during thermal degradation. Heliyon 1, e00034.

Brasier, M., McLoughlin, N., Green, O., Wacey, D. (2006) A fresh look at the fossil evidence for early Archaean cellular life. Philosophical Transactions of the Royal Society B: Biological Sciences 361, 887-902.
Brasier, M.D., Antcliffe, J., SAunders, M., Wacey, D. (2015) Changing the picture of Earth's earliest fossils (3.5-1.9 Ga) with new approaches and new discoveries. Proceedings of the National Academy of Sciences 112, 4859-4864.

Cosmidis, J., Templeton, A.S. (2016) Self-Assembly of biomorphic carbon/ sulfur microstructures in sulfidic environments. Nature Communications 7, 12812.

CRAIG, H. (1954) Geochemical implications of the isotopic composition of carbon in ancient rocks. Geochimica et Cosmochimica Acta 6, 186-196.

De Gregorio, B.T., Sharp, T.G., Rushdi, A.I., Simoneit, B.R.T. (2011) Bugs or Gunk? Nanoscale Methods for Assessing the Biogenicity of Ancient Microfossils and Organic Matter. In: Golding, S.D., GuIKson, M. (Eds.) Earliest Life on Earth: Habitats, Environments and Methods of Detection. Springer Netherlands, Dordrecht, 239-289.

FunKE, A., ZIEGLER, F. (2010) Hydrothermal carbonization of biomass: A summary and discussion of chemical mechanisms for process engineering. Biofuels, Bioproducts and Biorefining 4, 160-177.

Garcia-Ruiz, J.M., Hyde, S.T., Carnerup, A.M., Christy, A.G., VAn KRANENDONK, M.J., WelHam, N.J. (2003) Self-Assembled Silica-Carbonate Structures and Detection of Ancient Microfossils. Science 302, 1194-1197.

Garcia-Ruiz, J.M., Melero-Garcia, E., Hyde, S.T. (2009) Morphogenesis of SelfAssembled Nanocrystalline Materials of Barium Carbonate and Silica. Science 323, 362-365.

Garcia-Ruiz, J.M., van ZuIlen, M.A., BACH, W. (2020) Mineral self-organization on a lifeless planet. Physics of Life Reviews 34-35, 62-82.

Higgins, L.J.R., Brown, A.P., Harrington, J.P., Ross, A.B., Kaulich, B., Mishra, B. (2020) Evidence for a core-shell structure of hydrothermal carbon. Carbon 161, 423-431.

Higgs, P.G., LeHMAN, N. (2015) The RNA World: molecular cooperation at the origins of life. Nature Reviews Genetics 16, 7-17.

Horita, J. (2005) Some perspectives on isotope biosignatures for early life. Chemical Geology 218, 171-186.

Hu, B., Wang, K., Wu, L., Yu, S.-H., Antonietti, M., Trtirici, M.-M. (2010) Engineering Carbon Materials from the Hydrothermal Carbonization Process of Biomass. Advanced Materials 22, 813-828.

Jacquemot, P., Viennet, J.C., Bernard, S., Le Guillou, C., Rigaud, B., Delbes, L., Georgelin, T., JABER, M. (2019) The degradation of organic compounds impacts the crystallization of clay minerals and vice versa. Scientific Reports 9, 20251.

JAVAUX, E.J. (2019) Challenges in evidencing the earliest traces of life. Nature 572, $451-460$.

LaMer, V.K. (1952) Nucleation in Phase Transitions. Industrial \& Engineering Chemistry 44, 1270-1277.

Le Guillou, C., Bernard, S., De la Pena, F., Le Brech, Y. (2018) XaneS-Based Quantification of Carbon Functional Group Concentrations. Analytical Chemistry 90, 8379-8386.

Li, J., Bernard, S., Benzerara, K., Beyssac, O., Allard, T., Cosmidis, J., Moussou, J. (2014) Impact of biomineralization on the preservation of microorganisms during fossilization: An experimental perspective. Earth and Planetary Science Letters 400, 113-122.

Li, S., Pasc, A., Fierro, V., Celzard, A. (2016) Hollow carbon spheres, synthesis and applications - a review. Journal of Materials Chemistry A 4, 12686-12713.

Loron, C.C., François, C., Rainbird, R.H., Turner, E.C., Borensztajn, S., Javaux, E.J. (2019) Early fungi from the Proterozoic era in Arctic Canada. Nature 570, 232-235.

Mojzsis, S.J., Arrhenius, G., McKeegan, K.D., Harrison, T.M., Nutman, A.P., FRIEND, C.R.L. (1996) Evidence for life on Earth before 3,800 million years ago. Nature 384, 55-59.

Noorduin, W.L., Grinthal, A., Mahadevan, L., Aizenberg, J. (2013) Rationally Designed Complex, Hierarchical Microarchitectures. Science 340, 832-837.

PASTERIS, J.D., WOPENKA, B. (2003) Necessary, but Not Sufficient: Raman Identification of Disordered Carbon as a Signature of Ancient Life. Astrobiology 3, 727-738

Perry, E.C., LeFticariu, L. (2007) Formation and Geochemistry of Precambrian Cherts. Treatise on Geochemistry 7, 1-21.

Rouillard, J., García-Ruiz, J.-M., Gong, J., van Zuilen, M.A. (2018) A morphogram for silica-witherite biomorphs and its application to microfossil identification in the early earth rock record. Geobiology 16, 279-296.

SCHOPf, J.W. (1975) Precambrian Paleobiology: Problems and Perspectives. Annual Review of Earth and Planetary Sciences 3, 213-249.

Sevilla, M., Fuertes, A.B. (2009a) Chemical and Structural Properties of Carbonaceous Products Obtained by Hydrothermal Carbonization of Saccharides. Chemistry - A European Journal 15, 4195-4203. 
SEVILLA, M., Fuertes, A.B. (2009b) The production of carbon materials by hydrothermal carbonization of cellulose. Carbon 47, 2281-2289.

Viennet, J.-C., Bernard, S., Le Guillou, C., Jacquemot, P., Balan, E., Delbes, L., Rigaud, B., Georgelin, T., Jaber, M. (2019) Experimental clues for detecting biosignatures on Mars. Geochemical Perspectives Letters 12, 28-33.

Viennet, J.-C., Bernard, S., Le Guillou, C., Jacquemot, P., Delbes, L., Balan, E., JABER, M. (2020) Influence of the nature of the gas phase on the degradation of RNA during fossilization processes. Applied Clay Science 191, 105616.

WACEY, D. (Ed.) (2009) Early Life on Earth. Springer Netherlands, Dordrecht.

Wanger, G., Moser, D., Hay, M., Myneni, S., Onstott, T.C., Southam, G. (2012) Mobile hydrocarbon microspheres from $>2$-billion-year-old carbon-bearing seams in the South African deep subsurface. Geobiology 10, 496-505.

Westall, F. (2005) Early Life on Earth: The Ancient Fossil Record. In Ehrenfreund, P., Irvine, W.M., Owen, T., Becker, L., Blank, J., Brucato, J.R., Colangeli, L., Derenne, S., Dutrey, A., Despois, D., Lazcano, A., Robert, F. (Eds.) Astrobiology: Future Perspectives. Springer Netherlands, Dordrecht, 287-316. 